\title{
Malaysia's Need for an Enlightened National Policy on Interreligious Peace: A Dictate of Maqāṣidīal-Sharī ah
}

Osman Bakar*

As a nation, Malaysia is characteristically pluralistic and diverse in its cultural makeup. It is precariously balanced in its ethnic and religious compositions displaying a distributive pattern of cultural diversity in its demographic map in a way that is matched by few countries. Its pattern of cultural diversity is particularly distinguished by the fact that there is a close identification of religion with race. Malaysia is only barely a Muslim-majority country. It has a large non-Muslim population comprised mostly of Buddhists, Hindus, and Christians. There are other religious minorities such as Confucians, Taoists, and Sikhs though these are much smaller in size.

Most of the Muslims belong to the largest ethnic group, namely the Malays, while most of the Buddhists are ethnic Chinese and most of the Hindus are ethnic Indians. This close identification of religion with race has the important effect of making the two issues of inter-ethnic and interreligious peace closely intertwined. The issue of interreligious peace is therefore closely related to that of inter-ethnic peaceful coexistence. The two are intricately dependent on each other. In the light of this unique socio-cultural fact, the formidable challenge it poses to the future of stability and peace in Malaysia is well recognised.

Unfortunately, however, till now Malaysia does not have an enlightened national policy on interreligious peace that seeks to effectively address the delicate issues of interreligious relations. This is not to say that successive Malaysian leaders over the five decades of national independence have been unduly concerned with issues of national unity. On the contrary, these issues have been of paramount concern to the national leaderships. The only drawback perhaps is the apparent marginalisation of the religious dimension of national unity issues in government policies. This marginalisation is attested by the fact that since independence interreligious relations and their underlying issues have never occupied a central place in national discourses on inter-communal peace and national unity. While the country may be said to have an 'enlightened' and a pragmatic policy on inter-ethnic cooperation and peace, it does not have one on interreligious relations and peace.

True enough, save for the 13 May 1969 racial riots, Malaysia has been spared both ethnic and religious strife and conflict in the last fifty years. Even in the case of this sole national tragedy of real significance in the country's communal relations

* Professor Osman Bakar is the Deputy CEO of IAIS Malaysia. 
it was more of an ethnic conflict than a religious one. It is also true that Malaysians of different religious groups have interacted with each other peacefully in their daily lives - educational, business, political, and the workplace - but all these achievements have nothing to do with some well-defined policy on interreligious understanding and cooperation that the government of the day has put in place and enforced. It is to the credit of the Malaysian people that in spite of the absence of such a policy, relative interreligious peace has prevailed in the country. But of late many voices in the country have been heard expressing concerns about the sliding trends and developments in the country's interreligious relations that they feel must no longer be ignored if the relatively good national record of the absence of religious strife and conflicts were to be maintained and further improved.

If Malaysia is to have a proper national policy on interreligious relations and peace that one can really appreciate as enlightened in its approach and content then its leaders, both political and religious, need to address the various shortcomings in the past approaches or attitudes towards the challenge of religious diversity and pluralism in the country. In this Viewpoint I would like to identify and discuss two outstanding shortcomings visible in these past approaches and attitudes. The first shortcoming is what may be described as the government's 'hands off policy' when it comes to dealing with interreligious encounters and initiatives and contested religious issues. The government is over-cautious in its approach to interreligious issues to the point of being seen as avoiding confronting the real issues in interreligious relations in Malaysia. The second shortcoming is the subordination of the pursuit of interreligious peace to that of inter-ethnic peace.

Let me now deal briefly with the first shortcoming. The government's 'hands off policy' is to discourage or restrain citizens from conducting public discourses and debates on interreligious issues particularly when these issues involve the religion of Islam. The rationale for the discouragement or restraint is the fear that such discourses could easily run out of control to the point where there would not be anymore due mutual respect shown towards the religious sensitivities of the different religious communities. The ultimate concern in the mind of past Administrations is praiseworthy though, which is the maintenance of public order and interreligious peaceful existence.

But what in practice amounts to their 'non-policy policy' on interreligious issues has one major consequence on Malaysia's profile on the management of religious diversity and pluralism. It has the negative effect of discouraging and stifling or even intimidating interreligious dialogues in the country. Despite more than fifty years of national independence interreligious dialogue, as distinct from other forms of intercultural dialogues in which Malaysians have performed quite well, has not taken root in the country's multi-religious society to enable it to become an important aspect of Malaysian culture. On the contrary, opposition to interreligious dialogue 
from the conservative religious establishment has appeared to become stronger in recent years. In the absence of such a kind of dialogue, what prevailed in the public mind was the state-nourished view that religions are far more separated from each other than they are united. In other words, it is the view that there are more differences between religions than there are similarities or commonalities.

In the past, the government's appeal to the general public was to help promote religious tolerance through an inculcation of respect for existing differences between religions. But for some reason the content of this respect was never explained and thus left vague in the public mind. Without a concrete positive content and a strong ideational foundation, the respect in question could only be a fragile one. It is the acceptance of commonalities between religions that can help nurture true mutual respect. But these commonalities can only be unveiled to the public mind through an accumulative process of mutual understanding such as can be attained through healthy interreligious dialogues. Since such dialogues were absent, religious tolerance could hardly be developed on the basis of commonalities or shared perspectives which in the context of the social reality of the times remained largely hidden from the public eye.

What Malaysia now needs are more, and not less, interreligious dialogues. In fact, it is now long overdue for Malaysia to have a well-established and robust dialogue culture. Malaysia also needs to have more interreligious encounters and agendas in the form of conversations and discourses aimed at a far better mutual understanding between followers of the different religions and social initiatives such as educational and welfare works aimed at the common good of all citizens. All these interreligious initiatives can only be described as good for Malaysia. Far from intending to disrupt the interreligious peaceful coexistence and the level of religious harmony already in place in Malaysian society, these various initiatives are meant to improve upon them. These will certainly help to contribute to the realisation of Malaysian national unity and therefore also to the objectives of the 1Malaysia policy currently pursued by the administration of Prime Minister Mohd Najib Tun Abdul Razak.

Understandably, in pursuing the kind of interreligious encounters and agendas I have just outlined, caution is called for. The needed caution is all the more understandable if we were to realise that the level of cultural literacy of the kind needed in multi-religious societies is still wanting among Malaysians. Still, I am sure there are many ordinary Malaysian citizens who are as concerned as the government with the likely abuses of freedom in interreligious encounters and agendas. This concern and caution notwithstanding, this group of citizens would also argue that there is really no better alternative to dialogue, however risky it might be.

Not doing anything to promote interreligious dialogue and cooperation is no less a danger to Malaysia's interreligious peace and harmony and therefore to 
its national unity than pursuing actively such dialogues and discourses without restraint and regulations. The only real choice for Malaysians, especially for the country's political and religious leaders, is to pursue interreligious dialogues and various other kinds of initiatives with a sense of social responsibility. It is mainly the responsibility of the government to formulate a national policy on interreligious peace that would include outlining the place and role of interreligious dialogue in nation building and providing enough guidelines to lay a solid foundation for the healthy development of a national dialogue culture.

The second shortcoming in past government approaches to the societal problem of religious diversity and pluralism is to view it as of lesser strategic importance to national unity than the issue of inter-ethnic relations. The subordination of religious to ethnic considerations in the tackling of national issues is clearly reflected in many government policies, particularly in the educational and economic sectors. It is my strong view that this policy needs to be thoroughly reviewed. This would require current positions on the interrelationship between religion and ethnicity in the Malaysian context to be reviewed as well. It is not the aim of this recommendation to do away altogether with the ethnic factor in the formulation of national policies. To do so would be unrealistic and unnatural, and even futile, since ethnic consciousness is something natural to man. Ethnicity and ethnic considerations will always have a place and a role to play in Malaysia's national policies and in national life.

Rather, the recommendation made here is that on a wide range of national issues and problems religion ought to be recognised as a far more relevant and potent societal force than ethnicity in providing their solutions. Even the inter-ethnic relations themselves in both content and direction can best be served by religion, more particularly by shared spiritual and moral-ethical values to be found in Malaysia's religions. Community leaders representative of the different religious and ethnic groups are urged to reexamine their views on the respective roles of religion and ethnicity in Malaysian society and to highlight their new roles in a more concrete manner than hitherto presented in addressing such fundamental issues as interreligious peace and harmony, national development, national unity, and civilisational development.

The fact that Malaysians are becoming more assertive in religious matters than ever before and the fact that religious revival is to be observed not only among Muslims but also among followers of other religions dictate the reexamination of the role of religion in Malaysian society as a matter of great urgency. The new religious assertiveness has caused increasing interreligious tension in the country. The Malaysian government is therefore called upon to formulate a viable national policy on interreligious relations with the help of the nation's experts in the related fields in question. 
Such a policy would be in full accord with the maqāssid al-sharī'ah which has been traditionally understood as the higher objectives of Islamic divine law and its universal philosophy. Maqāșid al-sharī'ah constitutes the core of Islamic societal teachings. The policy in question, if it were to be enlightened by the maqasșid al-shari 'ah would seek to diffuse interreligious tension and to create in its place a socio-cultural environment which is conducive to interreligious harmony, societal peace, and social justice. This is because all of these much sought after societal goals are embodied in the maquașid al-sharì ah.

To inculcate a true appreciation and respect among Malaysians for Islam's position as the official religion of the country, there is nothing better that Muslims can do than to offer to share with their fellow non-Muslim citizens the universal values and wisdom contained in the maqūșid al-sharì ${ }^{\prime} a h$. In short, maqūșid al-sharī $a h$ dictates the formulation of an enlightened national policy on interreligious peace for Malaysia. In consequence, the panel or council of experts to be chosen to help formulate the policy in question must include experts on the higher objectives of Islamic law. 